\title{
Effects of Liming and Fertilization on Yields and Foliar Composition of High-Yielding Sun-grown Coffee in Puerto Rico ${ }^{1}$
}

\author{
Fernando Abruña, José Vicente-Chandler, Luis A. Becerra, and \\ Ramón Bosque Lugo ${ }^{2}$
}

\section{INTRODUCTION}

Intensive coffee-production techniques combining the use of superior varieties planted close together in rows in full sunlight with proper erosion control, liming, fertilization, pruning, pest control, etc., as described by Vicente-Chandler et $a l .(19)^{3}$ are now widely accepted by progressive farmers throughout Puerto Rico. Whereas extensively managed shade-grown coffee in Puerto Rico responds only slightly to fertilization, as shown by Gómez et al. (7), intensively managed plantings require heavy fertilization. Abruña et al. (3) found that intensively managed coffee yielding about 1,500 pounds per acre on Alonso clay near Castañer responded very strongly to the application of 150 pounds of nitrogen and 150 to 300 pounds of potassium per acre yearly, but did not respond to phosphorus fertilization.

Lightly fertilized, shade-grown coffee does not generally respond to liming in Puerto Rico. McClelland $(10,11)$ found that coffee growing on acid Catalina clay did not respond to liming, and Bonnet, Riera, and LugoLópez (4) reported that shaded coffee yielding about 500 pounds of market coffee per acre also did not respond to liming on Alonso clay. GuiscafréArrillaga and Gómez ( 8 ) found that, although coffee growing on a soil with a $\mathrm{pH}$ of 5.5 to 6.0 did not respond to liming, that growing on a nearby soil of $\mathrm{pH} 4.0$ to 4.5 responded to the application of up to 1 ton of limestone peracre.

There is little information on the response of heavily fertilized, highyielding sun-grown coffee to liming. Abruna, Vicente-Chandler, and Silva (3) have shown that such coffee responds strongly to fertilization with nitrogen and potassium. Such heavy fertilization with residually acid materials can rapidly increase soil acidity and loss of bases, as shown by

1 This paper reports work carried out cooperatively between the Soil and Water Conservation Research Division, Agricultural Research Service, USDA, and the Agricultural Experiment Station, University of Puerto Rico, Río Piedras, P.R.

${ }^{2}$ Soil Scientist, and Project Supervisor, Soil and Water Conservation Research Division, Agricultural Research Service, USDA, stationed at Rio Piedras, P.R.; private agronomist, Jayuya, P.R., and Assistant Agronomist in Charge, Adjuntas Substation of the Agricultural Experiment Station of the University of Puerto Rico, Rio Piedras, P.R., respectively.

3 Italic numbers in parentheses refer to Literature Cited, pp. 427-8. 
Pearson, Abruña, and Vicente-Chandler (14), with a resulting increase in the availability of soil manganese and/or aluminum which can be toxic even to grasses, as shown by Abruña, Vicente-Chandler, and Pearson (2).

The present studies were conducted to determine 1 , the fertility requirements of intensively managed sun-grown coffee under favorable climatic conditions typical of much of the Coffee Region of Puerto Rico, and 2, the effects of liming on yields and foliar composition of heavily fertilized, high-yielding sun-grown coffee, and on soil condition at two locations in the Mountain Region of Puerto Rico. A survey was also conducted to determine on which soil types liming was likely to be especially critical with intensively managed coffee.

\section{MATERIALS AND METHODS}

\section{FERTILIZER EXPERIMENTS}

Two experiments were carried out near Jayuya at an elevation of about 2,500 feet with mean monthly temperatures varying from $70^{\circ}$ to $80^{\circ} \mathrm{F}$., and about 90 inches of rainfall fairly well distributed throughout the year. The soil is steep, eloded Los Guineos clay on an unprotected site with a north to northeast exposure. The upper 6 inches of soil had the following characteristics:

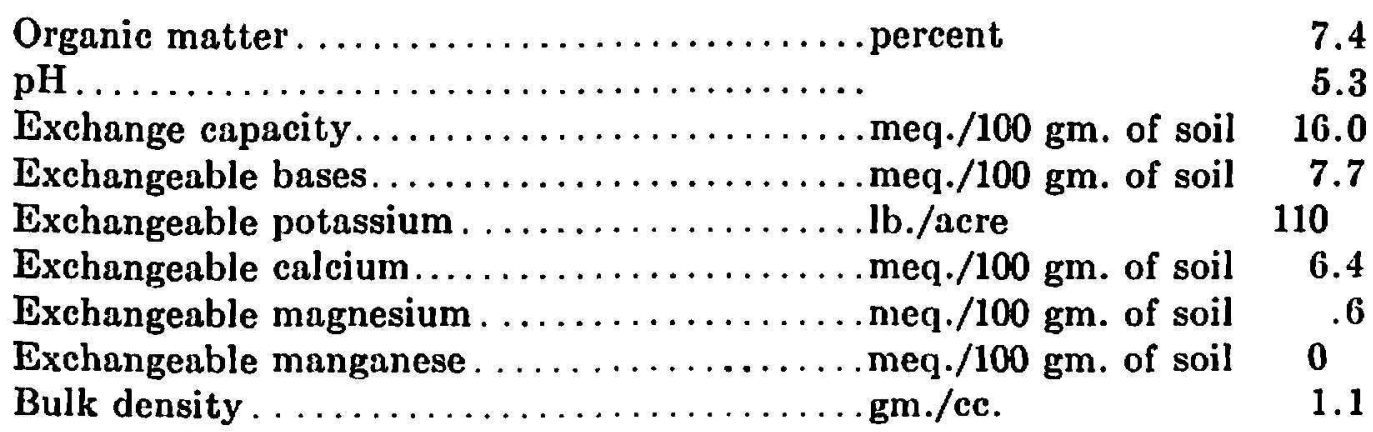

Experiment A was planted in 1958 and experiment B was started 1 year later in an adjacent area. Arabica coffee of the Bourbon variety was planted in hedges (fig. 1) 10 feet apart with 1,400 trees per acre. The hedges were kept free of weeds but grass, mowed periodically, was allowed to grow between hedges to control erosion. The coffee trees were sprayed twice yearly with a mixture of parathion and dieldrin to control the coffee leaf miner. Zine sulfate was added to the spray to correct symptoms of a deficiency of zinc. After each crop, old, broken, weak, or diseased branches and excess suckers were removed from the trees.

The fertilizer treatments tested, consisting of levels of the various nutrients varied in the presence of an abundance of all other nutrients, are shown in table 1. A randomized-block design was used, with all treatments replicated four times in experiment $\mathrm{A}$ and six times in experiment $\mathrm{B}$. 


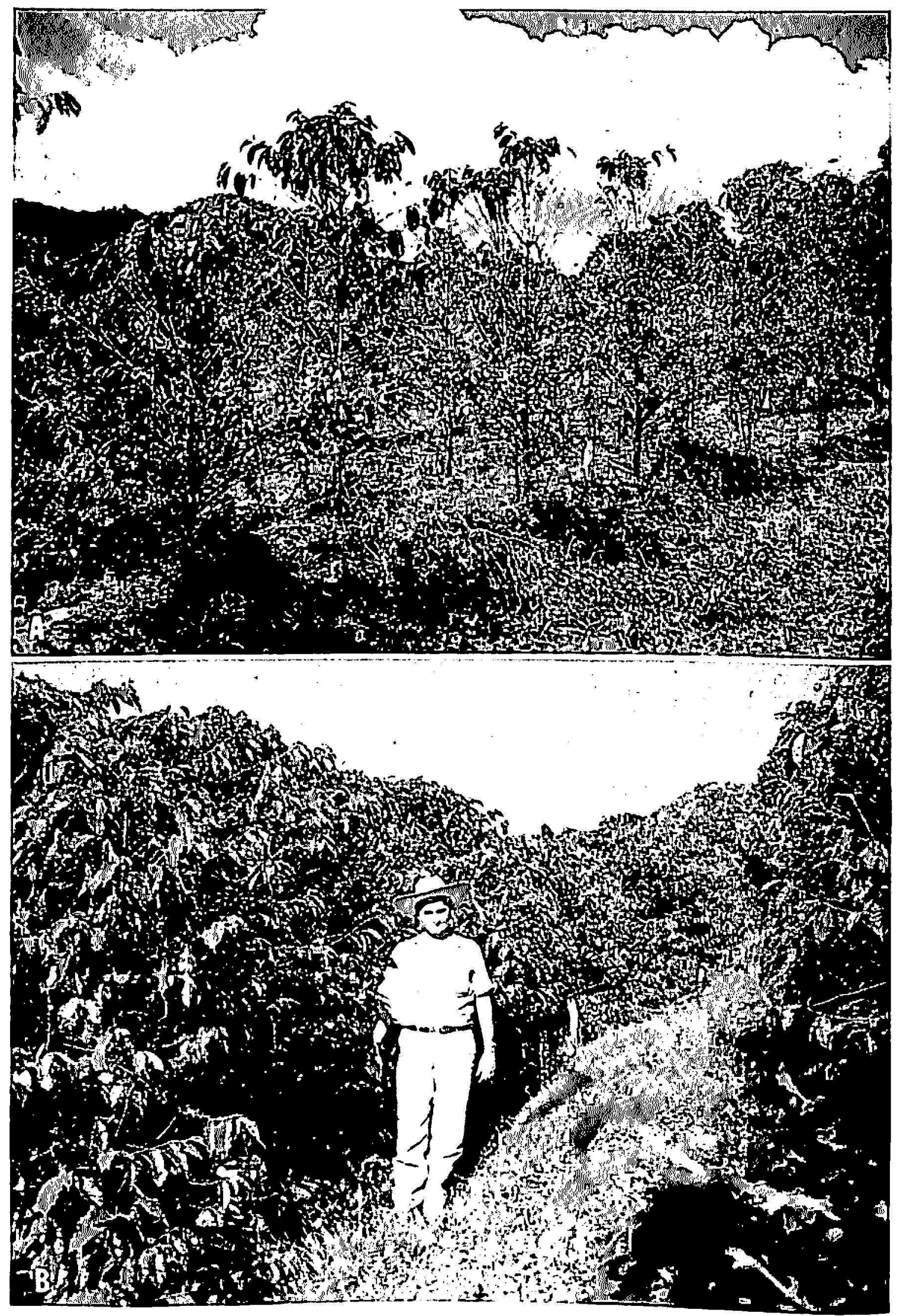

FIG. 1.- Effect of nitrogen and potassium fertilization on growth of intensively managed sun-grown coffee at Jayuya: A, Unfertilized; B, 300 pounds of nitrogen and 300 prounds of potassium applied per acre yearly in 3 applications. 
Individual plots consisted of 12 trees in a hedge. Fertilizer was applied under the hedges in three equal applications yearly in April, August, and December. Nitrogen was applied as ammonium sulfate, phosphorus as 20percent superphosphate, potassium as potassium chloride, and magnesium as magnesium sulfate. Two tons of limestone per acre were applied to all plots 1 year after planting and again 2 years later.

Coffee berries were picked from each plot as they ripened and yields of market coffee determined. Yields were determined for 3 consecutive years,

TABLE 1-Effect of fertilization on yields and foliar composition of sun-grown coølee on Los Guineos clay at Jayuya

\begin{tabular}{|c|c|c|c|c|c|c|c|c|c|}
\hline \multirow{2}{*}{ No. } & \multicolumn{4}{|c|}{$\begin{array}{l}\text { Fertilizer applied } \\
\text { per acre yearly }\end{array}$} & \multicolumn{2}{|c|}{$\begin{array}{l}\text { Yields of market } \\
\text { coffee per acre }\end{array}$} & \multicolumn{3}{|c|}{$\begin{array}{c}\text { Composition of coffee leaves' } \\
\text { (dry-weight basis) }\end{array}$} \\
\hline & $\mathbf{M g}$ & $x$ & $\mathrm{P}_{2} \mathrm{O}_{3}$ & K & Expt. A & Expt. B & $N$ & $\mathbf{P}$ & $\boldsymbol{K}$ \\
\hline & $L b$. & $L b$. & Lb. & $L b$. & $L b$. & $L b$. & Pcrcent & Percent & Percent \\
\hline 1 & 0 & 0 & 0 & 0 & 1,274 & - & 2.23 & 0.15 & 2.18 \\
\hline 2 & 200 & 300 & 200 & 600 & 2,584 & 3,263 & 2.70 & .17 & 2.53 \\
\hline 3 & 200 & 0 & 200 & 600 & 1,440 & - & 2.12 & .20 & 2.92 \\
\hline 4 & 200 & 150 & 200 & 600 & 2,378 & 2,563 & 2.50 & .18 & 2.62 \\
\hline 5 & 0 & 300 & 200 & 600 & 3,285 & - & 2.66 & .17 & 2.74 \\
\hline 6 & 200 & 300 & 0 & 600 & 2,263 & - & 2.73 & .15 & 2. (iki \\
\hline 7 & 200 & 300 & 100 & 600 & 2,933 & 3,343 & 2.74 & .17 & 2.61 \\
\hline 8 & 200 & 300 & 200 & 0 & 1,153 & - & 2.78 & .17 & 1.39 \\
\hline 9 & 200 & 300 & 200 & 300 & 2,315 & 3,1000 & 2.75 & .17 & 2.28 \\
\hline 10 & 200 & 300 & 200 & 1,200 & 2,278 & 3,333 & 2.77 & .17 & 2.88 \\
\hline 11 & 200 & 450 & 200 & 1,200 & 2,673 & 3,093 & 2.85 & .18 & 2.610 \\
\hline 12 & 100 & 300 & 200 & (i00 & 2,393 & 3,153 & 2.84 & .16 & 2.60 \\
\hline 13 & 200 & 150 & 200 & 300 & - & 2,700 & 2.52 & .15 & 2.60 \\
\hline 14 & 200 & 600 & 200 & 1,500 & - & 3,247 & 2.96 & .15 & 2.69 \\
\hline L.S.D. & & & & & & & & & \\
\hline 05 & & & & & 960 & 580 & & & \\
\hline 01 & & & & & 1,290 & 775 & & & \\
\hline
\end{tabular}

1 Spring of 1962 .

start ing 3 years after planting, since Machado (9) has shown that little is to be gained by prolonging fertilizer experiments with coffee beyond the first cycle of bearing. In the spring of 1962 a sample of mature, healthy leaves from the third or fourth pair from the tips was taken from the eight, trees in the center of each plot and analyzed for nitrogen, phosphorus, and pot assium.

\section{LIMING EXPERIMENTS}

Two experiments were conducted, one on Alonso clay, a latosol with predominantly kiolinitic clay minerals and high in free iron and aluminum 
oxides, near Adjuntas at an elevation of 2,000 feet, with 65 inches of annual rainfall, and the other on Los Guineos clay, a Red-Yellow podsol, near Jayuya at an elevation of 2,800 feet with 90 inches of annual rainfall.

Coffee of the Bourbon variety was planted in hedges 10 feet apart with 1,400 plants per acre and the plantation was treated as described above. All plots were fertilized with 300 pounds of nitrogen as ammonium sulfate, 100 pounds of phosphoric acid as 20 -percent superphosphate, 400 pounds of potassium as potassium chloride, and 60 pounds of magnesium as mag-

TABLE 2.-EJect of liming on yields and foliar composition of heavily fertilized sungrown coffee at two locations in the Coffee Region

\begin{tabular}{|c|c|c|c|c|c|c|c|}
\hline \multirow{2}{*}{$\begin{array}{c}\text { Limestone applied } \\
\text { per acre } \\
\text { (tons/acre) }\end{array}$} & \multirow{2}{*}{$\begin{array}{l}\text { Yields of market } \\
\text { coffee }^{1}\end{array}$} & \multicolumn{6}{|c|}{ Composition of coffee leaves ${ }^{2}$ (dry-weight basis) } \\
\hline & & $\mathbf{N}$ & $\mathbf{P}$ & $\mathbf{K}$ & $\mathrm{Ca}$ & $\mathbf{M g}$ & $\mathbf{M n}$ \\
\hline
\end{tabular}

Alonso clay near Adjuntas

\begin{tabular}{l|c|c|c|c|c|c|c}
\hline & Lb./acre & Percent & Percent & Percent & Percent & Percent & P.p.m. \\
0 & 1,700 & 3.11 & 0.14 & 2.01 & 0.52 & 0.50 & 292 \\
1.5 & 1,770 & 3.22 & .15 & 2.13 & .52 & .60 & - \\
3 & 1,590 & 2.89 & .15 & 2.08 & .61 & .56 & - \\
8 & 1,690 & 2.89 & .16 & 2.20 & .68 & .56 & 235 \\
\hline
\end{tabular}

Los Guineos clay at Jayuya

\begin{tabular}{l|r|r|r|r|r|r|r}
\hline 0 & 2,260 & 2.96 & 0.14 & 2.72 & 0.63 & 0.25 & 144 \\
2 & 2,820 & 2.95 & .17 & 2.69 & .78 & .28 & 113 \\
4 & 2,790 & 2.83 & .15 & 2.66 & .83 & .27 & 116 \\
6 & 2,530 & 2.76 & .16 & 2.58 & .94 & .28 & 110 \\
\hline
\end{tabular}

1 Average of 4 heavy crops.

24 years after limestone was applied.

nesium sulfate per acre yearly in three equal applications in April, August, and December.

Limestone, at rates shown in table 2, was applied to the soil surface at start of the experiments. A randomized-block design was used with all treatments replicated 5 times in each experiment. Individual plots consisted of 12 trees in a hedge.

Yields of market coffee were determined for cach plot as described above for 4 consecutive years, starting 3 years after planting, when the first heavy crop was produced. Before the third heavy crop, leaf samples were taken as described from eight trees in the center of each plot, and analyzed for nitrogen, phosphorus, potassium, calcium, magnesium, and manganese.

The surface soil in all plots on Los Guineos clay and in the plots limed with 0 and 8 tons on Alonso clay was also sampled at this time. The 
samples were air-dried and passed through a 20-mesh screen. Exchangeable aluminum was determined by extraction with potassium chloride as described by Pratt and Blair (17), and analyzed by the method described by Frink and Peech (6). Soil reaction was measured with a glass-electrode pH-meter using a 1:1.5 soil-water suspension. Exchangeable cations were extracted by the ammonium acetate extraction procedure described by Peech et al. (15). Calcium and magnesium were determined by the Versenate method as described by Cheng and Bray (5). Potassium was determined with a Coleman flame photometer and manganese by oxidation with periodate as described by Peech et al. (15).

As a complementary study, over 700 samples representing major soil types were taken throughout the Mountain Region. These samples were analyzed for $\mathrm{pH}$ and easily reducible manganese, following the method described by Sherman et al. (18).

\section{RESULTS AND DISCUSSION}

\section{FERTILIZER EXPERIMENTS}

The coffee grew exuberantly (fig. 1,B) and produced extremely high yields during all 3 years, properly fertilized plots yielding close to 3,000 pounds of market coffee per acre yearly, or 20 times the Islandwide average for extensively managed shade-grown coffee. Such very high yields resulted from the application of all required practices, together with favorable climatic conditions typical of much of the Coffee Region.

Table 1 shows that coffee responded very strongly to the application of 300 pounds of nitrogen per acre yearly (treatments $3 \mathrm{vs} .2$ in experiment $\mathrm{A}$, and treatment $4 v s .2$ in experiment B), but yields were not further increased by heavier applications of this nutrient (treatments $2 v s .11$ and 14). It is significant that coffee responded strongly to an increase in nitrogen fertilization from 150 to 300 pounds per acre at both the 600 - and the 300 -pound potassium rates (treatments $4 v s$. 2, and $13 v s .9$, respectively, in experiment B).

Coffec also responded very strongly to the application of 300 pounds of potassium per acre yearly (treatment $8 v s .9$ in experiment A), but yields were not further increased by heavier applications of this nutrient (treatments 9 vs. 2, 10,11, and 14).

The response of coffee to applications of both nitrogen and potassium is illustrated in figure 1. Data from both experiments combined in figure 2 show how coffee responded in yield to nitrogen and potassium fertilization during each of the three crops.

Table 1 shows that nitrogen and potassium contents of the coffee leaves increased sharply with increasing applications of these nutrients. Nitrogen 
content of the leaves increased from an average of 2.12 to 2.96 percent as nitrogen rates were increased from 0 to 600 pounds per acre, and potassium content increased from 1.39 to 2.88 percent as potassium rates were increased from 0 to 1,200 pounds per acre yearly.

Figure 3 shows that there was a statistically significant relationship between the nitrogen and potassium contents of the leaves in the spring of 1962 and yields obtained in the fall of that year. These data suggest
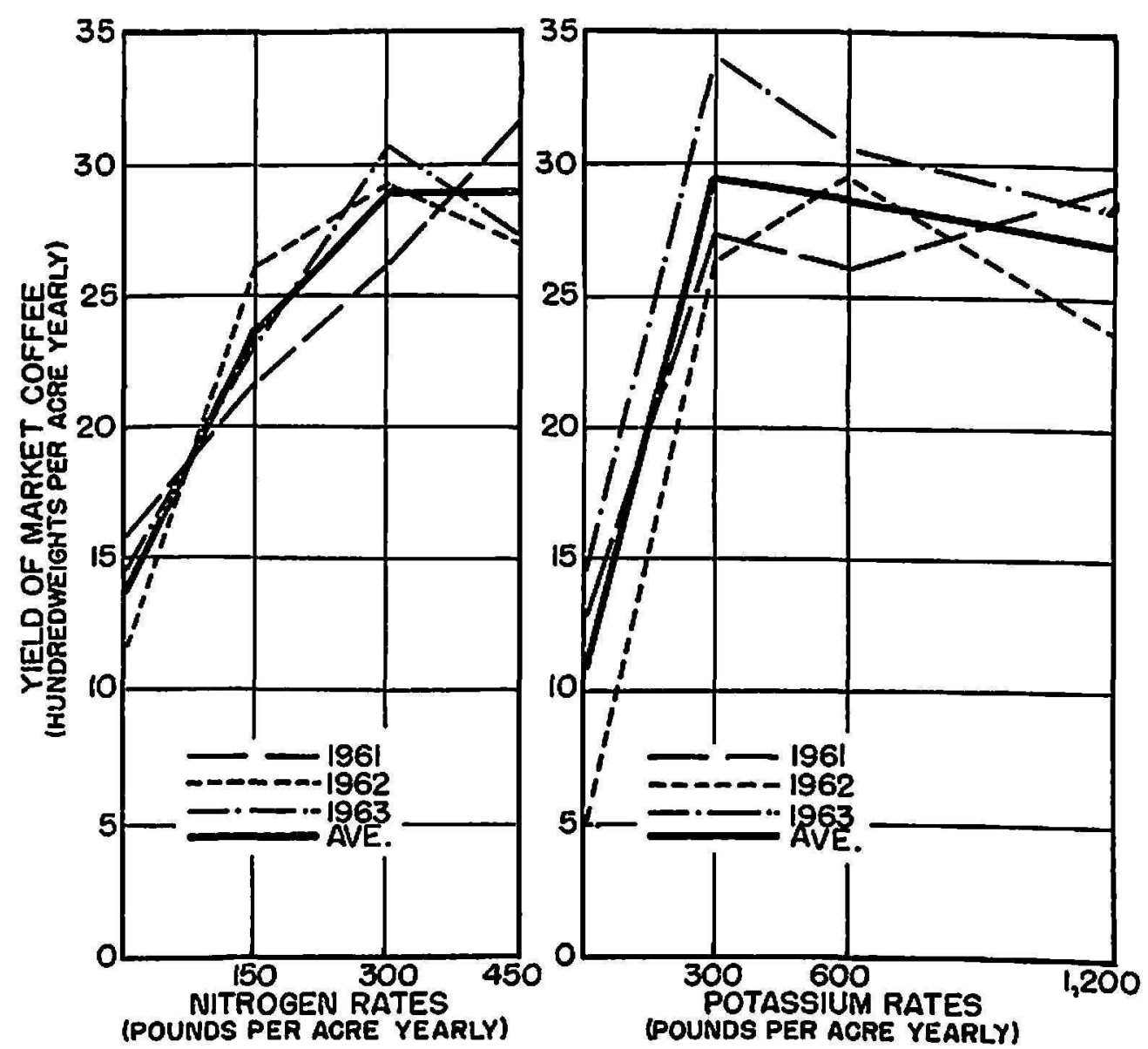

Frg. 2.-Effect of nitrogen and potassium fertilization on yields of intensively managed sun-grown coffee over a 3 -year period at Jayuya, P.R.

that leaf nitrogen and potassium contents of 2.5 to 3 percent are required for the production of high yields of coffee.

Heavy applications of potassium resulted in an accumulation of this nutrient in available form in the soil. At the end of 4 years the upper 18 inches of soil in plots receiving no potassium contained only 173 pounds of available potassium per acre as compared with 1,765 pounds in plots which had received 1,200 pounds of potassium per acre yearly.

Coffee did not respond to phosphorus or magnesium applications in either experiment, as shown in table 1. 
It can be concluded that the application of 300 pounds each of nitrogen and potassium per acre yearly in three applications is sufficient to sustain yields in the neighborhood of 3,000 pounds of market coffee per acre under typical conditions in the Coffee Region of Puerto Rico. The use of such large quantities of fertilizer is clearly economical, since their application increased yields by about 1,000 pounds of market coffee worth over $\$ 400$ on the world market, compared to fertilizer costs of about $\$ 60$. Proportionately

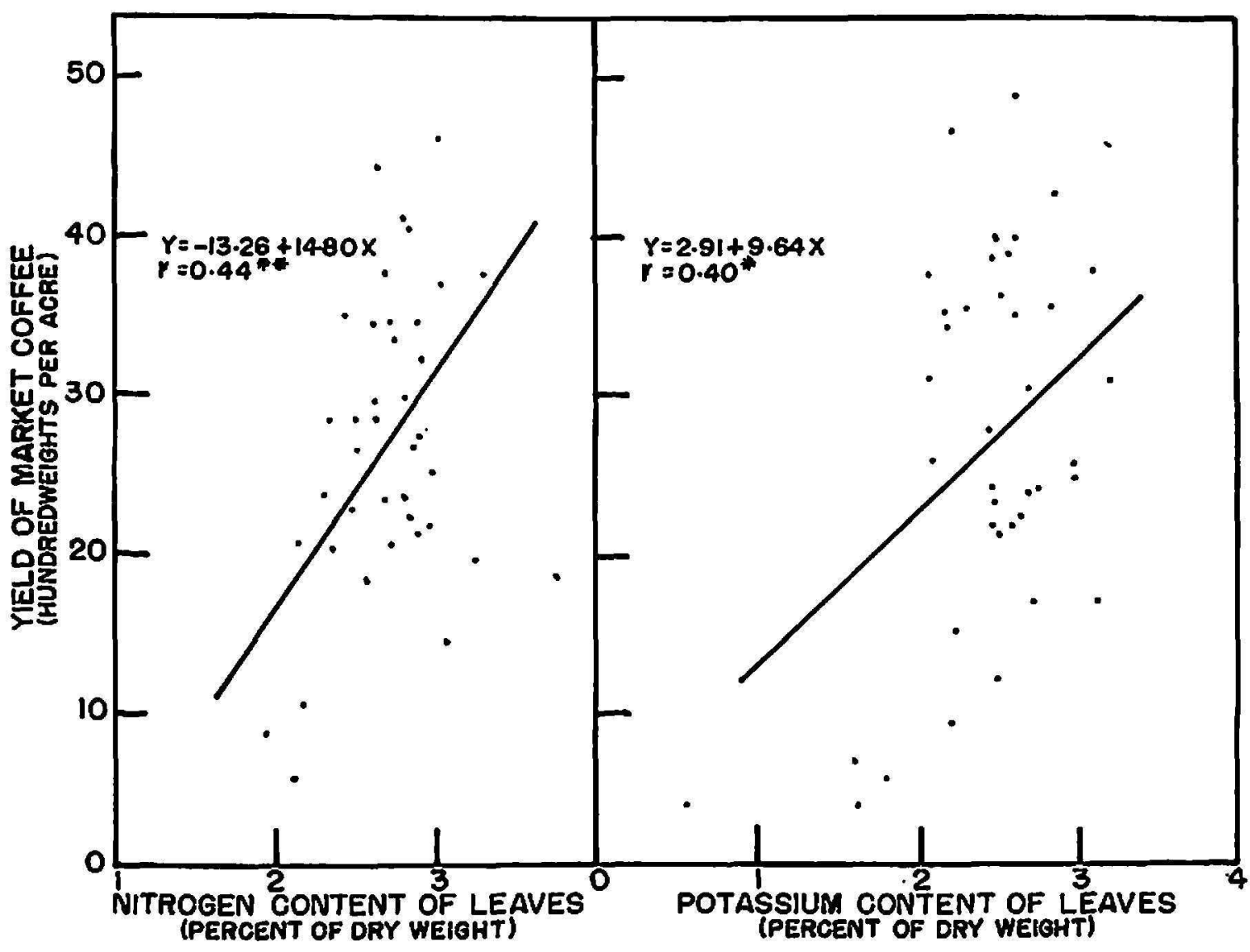

FIG. 3.-Relationship between nitrogen and potassium content of coffee leaves and yields (1962 crop).

less fertilizer may be used where climatic or other factors limit yields to lower levels.

\section{LIMING EXPERIMENTS}

Liming had no significant effect on yiclds of coffee in either experiment during any year or combination of yeurs (table 2), and yields remained high in all plots throughout the course of the experiment. Liming had no effect on incidence of coffee root rot.

Liming increased the calcium content of the coffee leaves in both experiments (table 2), particularly on Los Guineos clay, where calcium content 
was increased from 0.63 to 0.94 percent by heavy liming. Liming did not significantly affect the nitrogen, phosphorus, potassium, or magnesium content of the coffee leaves in either experiment, but slightly decreased their manganese content.

Soil $\mathrm{pH}$ and exchangeable-base content determined 4 years after liming increased with lime rates (table 3). However, much of the limestone had apparently leached into the subsoil as a result of the heavy applications of

TABLE 3.-Effect of initial liming on condition of the surface 6 inches of 2 soils following 4 years in heavily fertilized coffee

\begin{tabular}{c|c|c|c|c}
\hline $\begin{array}{c}\text { Limestone applied } \\
\text { (tons/acre) }\end{array}$ & $\mathrm{pH}$ & $\begin{array}{c}\text { Exchangeable } \\
\mathrm{Ca}+\mathrm{Mg}_{8}\end{array}$ & $\begin{array}{c}\text { Exchangeable } \\
\text { aluminum }\end{array}$ & $\begin{array}{c}\text { Exchangeable } \\
\text { manganesc }\end{array}$ \\
\hline & Alonso clay ${ }^{1}$ \\
\hline & & Meq./100 sm. of soil & P.p.m. & P.p.m. \\
0 & 4.0 & 1.67 & 270 & 10 \\
8 & 6.1 & $22.61^{2}$ & 0 & 6 \\
\hline
\end{tabular}

Los Guineos clay

\begin{tabular}{c|l|l|l|l}
\hline 0 & 3.9 & 1.75 & 345 & 0 \\
2 & 3.9 & 2.41 & 252 & 0 \\
4 & 4.4 & 4.87 & 188 & 0 \\
6 & 4.7 & 4.67 & 113 & 0 \\
\hline \hline Original soil & 4.8 & 2.70 & 60 & 2 \\
\hline
\end{tabular}

1 This soil had an average organic-matter content of 4.7 percent and a total cation exchange capacity of $16.4 \mathrm{meq} .100 \mathrm{gm}$. of soil.

2 There was some unreacted lime resulting from liming.

${ }^{3}$ This soil had an average organic-matter content of 4.7 percent and a total cationexchange capacity of $19.4 \mathrm{meq} .100 \mathrm{gm}$. of soil.

acid-residue fertilizers [Abruña, Vicente-Chandler, and Pearson (2), and Pearson, Abruña, and Vicente-Chandler (14)].

Liming strikingly decreased the exchangeable aluminum content of both soils from an average of 307 p.p.m. in the unlimed plots to 56 p.p.m. in the heavily limed plots (table 3 ). Since these soils had almost no exchangeable manganese it was impossible to determine the effect of liming on this nutrient.

The above data clearly show that high yields of coffee can be produced on soils such as those studied at $\mathrm{pH}$ 's as low as 4.0 with exchangeable bases as low as 2.0 meq. per $100 \mathrm{gm}$. of soil and exchangeable aluminum as high as 350 p.p.m. Even at this high level of acidity the soils apparently con- 
tained sufficient calcium as a nutrient for the coffee trees; exchangeable aluminum was below toxic levels; and available manganese content of the soil remained low.

The situation is very different, however, with soils high in readily available manganese, such as occur in many coffee-growing areas of Puerto Rico. Soon after the intensive coffee-production techniques described by VicenteChandler, et al. (19) came into use, several plantations evidencing alarming symptoms were brought to the attention of the authors. In the initial stages, margins of the coffee leaves became deep yellow, followed by yellowing of the young leaves. In later stages, older leaves dropped off and bearing branches lost most of their berries. This was soon followed by dieback and in some cases by death of the trees (fig. $4, \mathrm{~A}$ ). Leaf analysis revealed normal contents of all nutrients except manganese. Affected leaves contained 1,000 to 2,500 p.p.m. of this nutrient compared with 100 to 200 p.p.m. for normal leaves. Furthermore, soil analysis revealed extremely high contents of easily reducible manganese and high soil acidity. These data, and the fact that the condition was aggravated by fertilization, which increased availability of the manganese by increasing soil acidity, and was more severe following rains after a drought, since drying makes soil manganese more available, led the authors to conclude that the condition resulted from a manganese toxicity.

Two severely affected plantings were treated with 4 tons of limestone per acre distributed under the coffee rows (fig. 4 ) followed by applications of 1 ton of limestone for every ton of fertilizer applied. Two years later yields of market coffee had increased from about 600 pounds per acre to over 2,000 , the coffee leaves were deep green, and their manganese content had dropped to 300 to 400 p.p.m. The dramatic recovery of one of these plantations following liming is illustrated in figure 4,B.

In addition to liming, manganese toxicity may be alleviated by using fertilizers with a low residual acidity. Sources of nitrogen other than ammonium sulfate are preferable on high-manganese soils, since Abruña and Vicente-Chandler ( 1 ) found that applications of this salt greatly increased the uptake of manganese by coffee trees. Also, drying and heating, both of which release manganese, should be prevented wherever possible by mulching or irrigation. In older plantings shading of the surface soil by the coffee trees has an effect similar to that of mulching. Probably for this reason old plantings rarely exhibit as severe symptoms of manganese toxicity as do young trees.

Although manganese deficiency has received considerable attention in the world's literature on coffee, little is said of manganese toxicity. There is evidence, however, that this condition is widespread throughout coffeeproducing countries. Medcalf (12), in reporting that coffee responded 


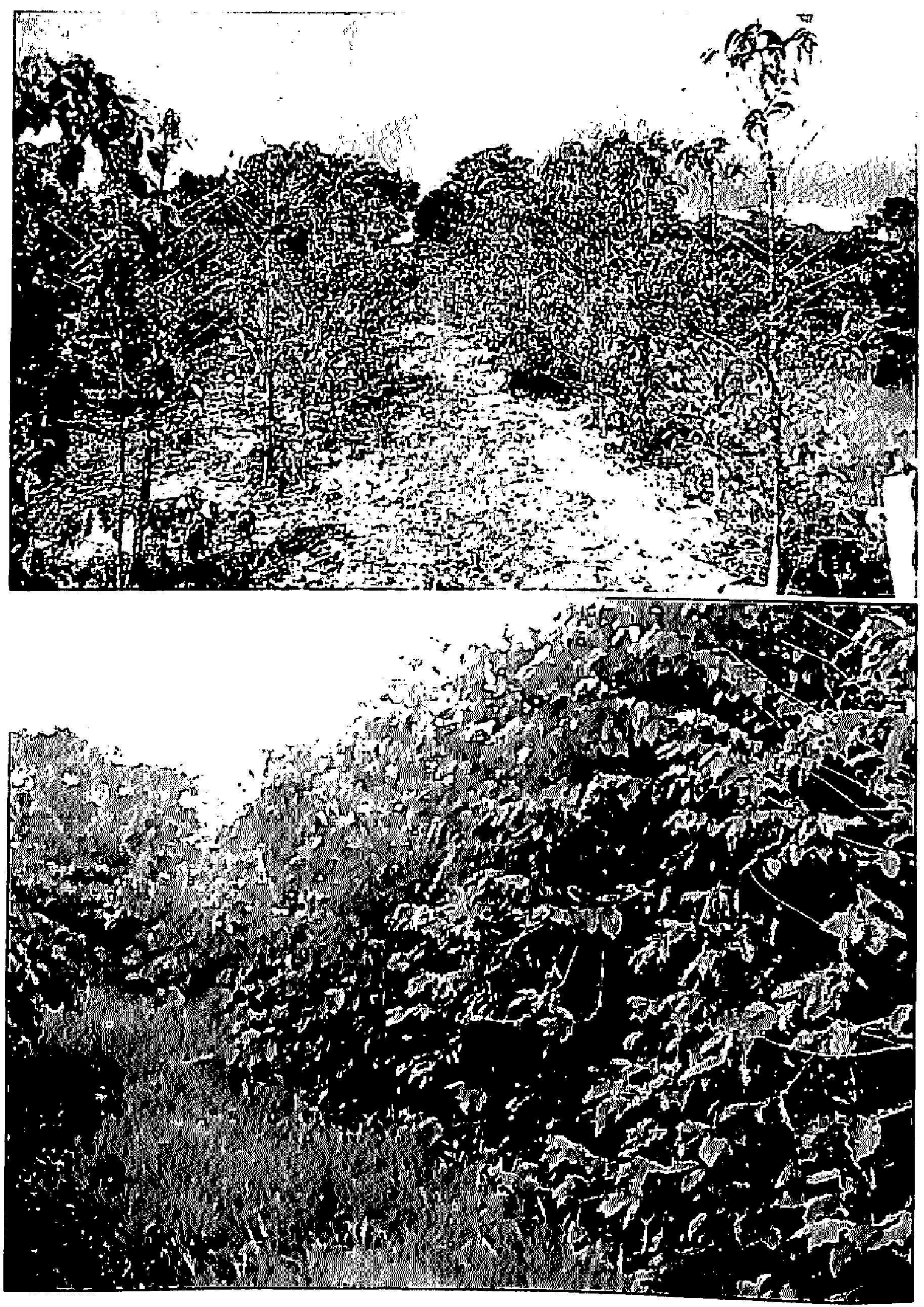

Fra. 4.- Effect of liming on intensively managed, well-fertilized sun-grown coffee severely affected by manganese toxicity: A, Lnlimed 3-year-old coffee trees evidencing severe symptoms of manganese toxicity; note heavy application of ground limestone made under the coffee rows the same day the photograph was taken. 13 , Same trees 2 years after application of 4 tons of ground limestone per acre; farm of Joaquín Roselló near Ciales 
strongly to mulching in Brazil, noted that leaves from the mulched plots contained 188 p.p.m. of manganese compared with 515 p.p.m. in unmulched plots. Medealf and Lott (13), in reporting that coffee responded strongly to applications of metal chelates in Brazil, noted that leaves from plots treated with chelates contained 522 p.p.m. of manganese compared with 1,133 p.p.m. for leaves from untreated plots which exhibited chlorotic symptoms. Also, Peralta (16) in Costa Rica, reported that coffee exhibiting abnormal flowering, mottled chlorosis of leaves, and death of apical buds contained an average of 804 p.p.m. of manganese in the leaves compared with 166 p.p.m. for healthy coffee. Other references in the litcrature to yellowing, leaf-fall, dieback, lack of response to fertilization, and such, might be explained by an unrecognized condition of manganese toxicity.

It is apparent that the need for liming coffee plantations in Puerto Riro is related both to soil acidity and readily available manganese content, both of which vary widely with soil type as shown in table 4 . These soils can be divided roughly into three main groups: 1 , Soils low in easily reducible manganese where toxicity is not a problem-e.g. Los Guineos, Moca, Utuado, Lares, and Ciales soils; 2 , soils high in easily reducible manganese, but with much less acidity and a higher base content, where manganese toxicity is not an immediate problem-e.g. Múcara and Descalabrado soils; 3 , acid soils high in easily reducible manganese where toxicity is likely to be an immediate and serious problem-e.g. Cialitos, Jayuya, Alonso, and Catalina soils.

Although soil type gives an indication of where manganese toxicity is likely to be a problem, there is considerable variability within soil types. Therefore, foliar analyses, complemented whenever possible by data on soil acidity and manganese content, should be determinant. Although the rritical levels of manganese in coffec leaves have not been determined, and although they may vary widely with season of the year and other factors, some general guides may be tentatively established. Leaf-manganese values in excess of 1,000 p.p.m. usually indicate a severe manganese toxicity, values of 500 to 1,000 p.p.m. indicate probable manganese toxicity, while values of 100 to 300 p.p.m. are considered normal.

It can be concluded that high yields of coffee can be produced on lowmanganese soils with no initial liming. On the other hand, in highmanganese soils, heavy initial applications of limestone should be made to raise soil pH 10 about 5.5. ${ }^{4}$ In both ('ises, 10 prevent increases in soil acidity, about 1 ton of limestone should thereafter be applied under the coffee rows for every ton of fertilizer used. Limestone should be applied about 2 months before fertilizing and, if heavy applieations are made, the coffee trees should

4 Soil samples should be taken under the coffee rows where most of the roots are and where the fertilizer is applied. 
be watched for symptoms of zinc or boron deficiencies which are acrentuated by liming.

There is little doubt that liming will become an increasingly important. practice in Puerto Rico and throughout the world as coffee production is intensified and heavy fertilization with acid-residue fertilizers becomes a common practice. In many cases liming can make the difference between success and failure in coffee production.

TABLE 4.-Average easily reducible manganese content (p.p.m.) and acidily of the major soilsof Puerto Rico's Mountain Region'

\begin{tabular}{l|c|c|c}
\hline Group and soil type & Approximate acreage & $\begin{array}{c}\text { Fasily reducible } \\
\text { manganese }\end{array}$ & $\mathrm{pH}$ \\
\hline $1:$ & & & \\
Los Giuineos & 70,000 & 100 & 4.5 \\
Moca & 20,000 & 13 & 5.8 \\
Uluado & 25,000 & 150 & 6.0 \\
Lares & 22,000 & 162 & 4.6 \\
Ciales & 12,000 & 200 & 6.0 \\
& & & \\
$2:$ & 210,000 & 345 & 4.0 \\
Cialitos & 10,000 & 424 & 5.2 \\
Jayuya & 25,000 & 590 & 5.0 \\
Alonso & 120,000 & 695 & 5.1 \\
Catalina & & & \\
$3:$ & 343,000 & 600 & 6.0 \\
Múcara2 & 96,000 & 760 & 6.9 \\
Descalabrado & & & \\
\hline
\end{tabular}

1 Values shown are averages of samples varying in number roughly in proportion to the acreage in each soil type.

2 These soils in relatively small proportion are found in the Coffee Region or are suited to intensive coffee production.

\section{SUMMARY}

The fertility requirements of high-yiclding, intensively managed sungrown coffee growing under favorable climatic conditions in the Mount ain Region of Pucrto Rico were studied.

About 3,000 pounds of matket coffee per acre yearly were produced when fertilization was adecuate. Coffee responded strongly to the application of 300 pounds of nitrogen and 300 pounds of potassium per acre yearly, in three equal applications. Leaf-nit rogen and -jolassium ('ontents of 2.5) 103.0 percent were assorjated with high yields. (Coffee did not respond to phosphorus or magnesium applications.

The effects of liming on yields and foliar composition of heavily fertilized, 
high-yielding, sun-grown coffee and on soil condition were determined in experiments at two locations in the Mountain Region of Puerto Rico. Soil types on which liming is likely to be especially critical were studied by analyzing soil samples obtained throughout the Mountain Region.

Liming had no significant effect on yields of coffee on either Alonso clay near Adjuntas or Los Guineos clay near Jayuya. Liming increased the calcium content and decreased the manganese content, but had no effect on the $\mathrm{N}, \mathrm{P}, \mathrm{K}$, or $\mathrm{Mg}$ content of the coffee leaves.

Liming increased soil $\mathrm{pH}$ and exchangeable-base content and sharply decreased the exchangeable-aluminum content of both soils. Both soils had a very low, easily reducible manganese content.

Severe symptoms of manganese toxicity in intensively managed coffec plantations on soils with a high manganese content were corrected by liming. The soils of the Coffee Region of Puerto Rico fall into three groups as to likelihood of manganese toxicity becoming a problem with intensively managed coffee: Soils low in easily reducible manganese where toxicity of this element is not a problem; soils high in easily reducible manganese, but high in bases and low in acidity where toxicity of this element is not an immediate problem; and acid soils high in easy reducible manganese where toxicity of this element is likely to be an immediate and serious problem.

\section{RESUME.}

Se estudiaron los nut rimentos necesarios para un cafetal de alta producción, cultivado intensivamente a pleno sol y bajo condiciones climáticas favorables en la Región Montañosa de Puerto Rico.

Con un adecuado abonamiento se obtuvieron rendimientos de aproximadamente 3,000 libras de café pilado por acre al año. Los cafetos respondieron grandemente cuando se le aplicaron al suclo 300 libras de nitrógeno y 300 de potasa por acre anualmente, divididas éstas en tres aplicaciones al año. Los altos rendimient os se obt uvieron cuando el contenido foliar de nit rógeno y potasio fue de 2.5 a 3.0 por ciento. Jos (afetos no respondieron, a lass aplicaciones de fósforo o de magnesio.

Mediante experimentos llevados a cabo en dos áreas de la Región Montatnosa de Puerto Rico se estudiaron los efectos de las aplicaciones de cal sobre la producción y composición de la hoja de los cafetos bien abonados y cultivados a pleno sol, así como sobre lia composición de los suelos. Conjuntamente, se tomaron muest ras de los suelos de la región para determinar en cuáles de ellos la loxicidad causada por el manganeso podría constituir III serio problema.

Lá aplicación de cal no redundó en aumentos significativos en la producrión de los cafetos en un suelo Alonso arcilloso cerea de Adjuntas, ni en el del tipo Los Guineos arcilloso, cerea de Jayuya. La aplicación de cal al 
suelo aumentó el contenido de culcio y disminuyó el de manganeso en las hojas de los cafetos, aunque no alteró el de nitrógeno, fósforo, potasio o magnesio.

La cal aumentó substancialmente el pH y el contenido de bases intercambiables del suelo, y disminuyó marcadamente el contenido de aluminio intercambiable. Ambos suelos tuvieron un bajo contenido de manganeso fácilmente reducible.

Mediante la aplicación de cal se corrigieron los síntomas de toxicidad severa causados por un exceso de manganeso en algunas plantaciones de café bajo cultivo intensivo. Los suelos de la Región Cafetalera de Puerto Rico pueden agruparse en tres categorías, según su capacidad de proveer manganeso en cantidades toxicas, a saber:

1. Suelos cuyo contenido de manganeso, por ser bajo, es de insignificante importancia en cuanto a su toxicidad.

2. Suelos que, aunque con un alto contenido fácilmente reducible, no presentan problemas inmediatos de toxicidad, debido a su baja acidez.

3. Suelos ácidos con un alto contenido de manganeso fácilmente reducible, cuya toxicidad a causa de este elemento presenta un problema grave y urgente.

\section{LITERATURE CITED}

1. Abruña, F., and Vicente-Chandler, J., Effects of six sources of nitrogen on yields, soil acidity, and leaf composition of coffee, J. Agr. Univ. P.R. 47 (1): 41-6, 1963.

2. Abruña, F., Vicente-Chandler, J., and Pearson, R. W., Effects of liming on yields and composition of heavily fertilized grasses and on soil properties under humid tropical conditions, Soil Sci. Soc. Amer. Proc. 28, (5): 657-61, 1964.

3. Abruña, F., Vicente-Chandler, J., and Silva, S., The effect of different fertility levels on yields of intensively managed coffee in Puerto Rico, J. Agr. Univ. P.R. 48 (3) : 141-6, 1959.

4. Bonnet, J. A., Riera, A. R., and Lugo-López, M. A., Lack of response of old coffee trees grown in Alonso clay to lime and phosphate fertilization, J. Agr. Univ. P.R. 42 (3) : 161-7, 1958.

5. Cheng, K. L., and Bray, R. H., Determination of calcium and magnesium in soil and plant material, Soil Sci. 78: 449-58, 1951.

6. Frink, C. R., and Peech, M., Determination of aluminum in soil extracts, Soil Sci. 98: 317-24, 1962.

7. Gómez, L. A., Leria-Esmoris, J., and Capó, B. G., Fertilizer requirements of coffee grown on Catalina clay in Puerto Rico, J. Agr. Univ. P.R. 80 (3): 127-37, 1946.

8. Guiscafré-Arrillaga, J., and Gómez, L. A., Agr. Expt. Sta., Univ, P.R., Annual Rpt., 48 pp., 1941.

9. Machado, A., Duración de un experimento de campo con cafetos en producción, Cenicafe 11 (10): 275-305, 1960.

10. McClelland, T. B., Some Profitable and Unprofitable Coffee Lands, B. 21, P.R. Fed. Agr. Expt. Sta., 1917.

11. - Experiments with Fertilizers for Coffec in Puerto Rico, B. 31, P.R. Agr. Expt. Sta., 1926. 
12. Medcalf, J. C., Preliminary Studies on Mulching Young Coffee in Brazil, B. 12, IBEC Research Institute, 30 Rockefeller Place, New York 20, N. Y.

13. Medcalf, J. C., and Lott, W. L., Metal Chelates in Cofiee, B. 11, IBEC Research Institute, 1956.

14. Pearson, R. W., Abruña, F., and Vicente-Chandler, J., Effect of lime and nitrogen applications on downward movement of calcium and magnesium in two typical humid soils of Puerto Rico, Soil Sci., 93: 77-82, 1962.

15. Peech, M., Alexander, L. T., Dean, L. A., and Reed, F., Methods of Soil Analysis for Soil-Fertility Investigations, USDA Circular 757, 1947.

16. Peralta, María E., Análisis de Algunos Minerales en Hojas de Café con y sin Afección de Café "Macho", (unpub. thesis), San José, Costa Rica, Univ. Nac. de C.R., 1952.

17. Pratt, P. F., and Blair, F. L., A comparison of three reagents for the extraction of aluminum from soils, Soil Sci. 91: 357-9, 1961.

18. Sherman, G. D., MeHargue, J. S., and Hodgekiss, W. S., Determination of active manganese in soil, Soil Sci., 54: 253-7, 1942.

19. Vicente-Chandler, J., Abruña, F., and Silva, S., A Guide to Intensive Coffee Culture, Prod. Res. Rpt. No. 31, ARS, USDA, 51 pp. 1959. 